\title{
Assessment of Water Quality as Provisional Ecosystem Service in Sacred Groves of Gwalior
}

\author{
Sangeeta Sharma ${ }^{1}$, Muzamil Ahmad Sheikh ${ }^{2}$, Avinash Tiwari ${ }^{3}$ \\ ${ }^{1,2,3}$ School of Studies in Botany, Jiwaji University, Gwalior, India
}

\begin{abstract}
Sacred groves (forest) are a group of trees or a patch of vegetation protected by the local people through religious and cultural practices evolved to minimize destruction. Provisioning ecosystem services are the material or energy outputs from ecosystems. Four sacred groves of Gwalior region provide provisional ecosystem services in the form of fresh water. The present study was carried out to evaluate the seasonal water quality status of four sacred groves of Gwalior from July 2013 to June 2014. Water bodies in these sacred groves were found in the form of flowing water and well water. Physicochemical parameters namely pH, EC, TDS, dissolved oxygen, total alkalinity, total hardness, calcium hardness, magnesium hardness, chloride, phosphate, sodium and potassium was analyzed using standard methods. Results of the study indicated that the fresh water supports the provisional ecosystem services of sacred groves and some conservation measures has to be taken to maintain its water quality.
\end{abstract}

Keywords: Provisional ecosystem service, Sacred groves, Water quality parameters

\section{Introduction}

Humankind benefits from ecosystems in a multitude of ways. Collectively, these benefits are known as ecosystem services. Provisioning services are ecosystem services that describe the material or energy outputs from ecosystems. They include food, water and other resources. Ecosystem services are regularly involved in the provisioning of clean drinking water and the decomposition of wastes. Fresh water ecosystem plays a vital role in the global hydrological cycle, as they regulate the flow and purification of water. Vegetation and forests get influenced by the quantity and quality of water available locally. Water is one of the most valuable natural resources as life without water is impossible to exist. The sacred groves of Gwalior provide this natural valuable resource as one of the main provisional ecosystem service. Water plays an important role for drinking, vegetation, wild life, recreation, aesthetic, etc., in these sacred groves. People's changing attitudes, erosion of traditional beliefs and human impact have caused degradation of sacred groves over the years. Therefore, the quantity and quality of water of these sacred groves are getting deteriorated as the people nowadays consider these sacred groves as picnic spots and perform useless activities which degrades the water quality.

\section{Materials and Methods}

Four sacred groves namely, Panchi K Baba (site 1), Mom K Hanuman ji (site 2), Kaner jhir (site 3) and Siddhkho (site 4) were selected from which water samples were taken (Table $1)$.

Flowing water was found in Panchi K Baba, Kaner jhir and Mom K Hanuman ji while in Siddhkho water was available in wells. The flowing water and well water was used by the local residents for drinking and domestic purpose. The quantity of water in site 1, site
Table 1: Site Description

\begin{tabular}{|c|c|c|c|c|}
\hline Site & Sacred grove & District & Latitude & Longitude \\
\hline 1. & Panchi K Baba & Gwalior & $26^{0} 13^{\prime} 58.3^{\prime \prime} \mathrm{N}$ & $78^{0} 10^{\prime} 58.1^{\prime \prime} \mathrm{E}$ \\
\hline 2. & Mom K Hanuman ji & Gwalior & $26^{0} 21^{\prime} 82.0^{\prime \prime} \mathrm{N}$ & $78^{0} 17^{\prime} 59.4^{\prime \prime} \mathrm{E}$ \\
\hline 3. & Kaner Jhir & Gwalior & $26^{0} 03^{\prime} 46.6^{\prime \prime} \mathrm{N}$ & $77^{0} 59^{\prime} 47.1^{\prime \prime} \mathrm{E}$ \\
\hline 4. & Siddhkho & Gwalior & $26^{0} 04^{\prime} 34^{\prime \prime} \mathrm{N}$ & $78^{0} 18^{\prime} 29^{\prime \prime} \mathrm{E}$ \\
\hline
\end{tabular}

2 and site 4 was more in rainy season as compared to winter and summer season whereas in site 3, water was found in good quantity throughout the year.

Water samples were collected on seasonal basis from all the four sites in one litre polyethylene bottles properly cleaned, labeled and were analyzed in laboratory for different physicochemical parameters (1). All the water samples were clear, colourless and odourless.

Parameters like $\mathrm{pH}$ and electrical conductivity were recorded at sampling sites whereas TDS, dissolved oxygen, total alkalinity, total hardness, calcium hardness, magnesium hardness, chloride, phosphate, sodium and potassium were analyzed in laboratory. Study period was divided into three phase i.e., Phase I from June to September, Phase II from October to January and Phase III from February to May.

\section{Methodology}

Standard methods and protocol were followed to carry out analysis (2).

- $\mathrm{pH}$ - Digital $\mathrm{pH}$ meter

- Electrical Conductivity - Digital electrical conductivity meter

- Dissolved Oxygen - Winkler method

- Total alkalinity - Titration method

- Total hardness - EDTA titrimetric method

- Calcium hardness - EDTA titrimetric method

- Magnesium hardness - EDTA titrimetric method

- Chloride - Argentometric method

- Phosphate - Stannous chloride method

- Sodium - Flame photometric method

- Potassium - Flame photometric method 


\section{International Journal of Science and Research (IJSR) \\ ISSN (Online): 2319-7064}

Index Copernicus Value (2013): 6.14 | Impact Factor (2014): 5.611

\section{Results \& Discussion}

\section{pH}

The $\mathrm{pH}$ of water ranged from 6.7 to 8.5 . The lowest value 6.7 was recorded at site 4 during phase II and the highest value 8.5 at site 2 during phase II (Graph 1). The high $\mathrm{pH}$ value may be due to increased organic compound degradation and the higher photosynthetic activity by macrophytes which results in decrease of $\mathrm{H}^{+}$concentration (10).

\section{Electrical Conductivity}

Electrical conductance values ranged from 155 to 666 $\mu \mathrm{S} / \mathrm{cm}$ and indicate the presence of ionic matters in water. The minimum value of 155 was recorded at site 2 during phase I and maximum value of 666 was recorded at site 1 during phase II (Graph 2). High value of conductivity is due to anthropogenic activities such as domestic waste which releases large amount of nutrients in water (9).

\section{TDS}

TDS is defined as the residue of filtered water sample after evaporation. The bulk of total dissolved solids include bicarbonates, sulphates and chloride of calcium, magnesium, sodium, potassium, silica, potassium chloride, nitrate and boron. TDS was calculated using the relationship given below (8):

$\operatorname{TDS}(\mathrm{ppm})=0.64 * \mathrm{EC}($ micromhos $/ \mathrm{cm})$

TDS of the water body ranged from 99.2 to $426.24 \mathrm{ppm}$. Subsequently, four classes of water were proposed based on the procedures (3) (Table 5).

Table 5: Water Quality Classification based on TDS (content by Carroll, 1962)

\begin{tabular}{|c|c|}
\hline TDS (in ppm) & Water Quality \\
\hline $0-1,000$ & Fresh water \\
\hline $1,000-10,000$ & Brackish water \\
\hline 10,000 to $1,00,000$ & Salty water \\
\hline$>1,00,000$ & Brine \\
\hline
\end{tabular}

The lowest value 99.2 was found at site 2 during phase I whereas the highest value 426.24 was recorded at site 1 during phase II (Graph 3). From table 5, it is cleared that the water sample is of fresh water.

\section{Dissolved Oxygen}

Dissolved oxygen is very important parameter as it reflects the biological activity taking place in a water body and determines the biological changes. Dissolved oxygen values of water ranged from 5.65 to $8.9 \mathrm{mg} /$ lit. The minimum value $5.65 \mathrm{mg} / \mathrm{lit}$ of DO was observed at site 1 during phase II while maximum value $8.9 \mathrm{mg} / \mathrm{lit}$ was recorded at site 3 during phase I (Graph 4). The DO at site 1 was found lower due to the effect of human activities such as washing, bathing, etc., where oxygen is used to decompose these organic wastes that causes algal blooms (9). The highest DO was reported at site 3 because of water flow and less human interferences.

\section{Total Alkalinity}

The alkalinity is the buffering capacity of water. The total alkalinity was observed between $70 \mathrm{mg} /$ lit to $310 \mathrm{mg} / \mathrm{lit}$. The lowest alkalinity $70 \mathrm{mg} /$ lit during phase I was found at site 4 whereas highest $310 \mathrm{mg} /$ lit was found at site 1 during phase I (Graph 5). The alkalinity gets increased due to the various religious activities, domestic waste and especially due to soaps and detergents (12). The alkalinity decreases due to onset of rains (14).

\section{Total hardness}

Hardness is often referred to as the soap consuming property of water. Cations imparting hardness are $\mathrm{Ca}^{+2}$ and $\mathrm{Mg}^{+2}$ whereas the anions responsible for hardness are carbonates, bicarbonates, sulphates, chlorides, nitrate and silicate. The total hardness ranged from 310 to $1090 \mathrm{ppm}$. The lowest total hardness $310 \mathrm{ppm}$ was found at site 2 during phase II whereas the highest total hardness 1090 was found at site 1 during phase I (Graph 6). The increase in the total hardness may be due to domestic activities like washing clothes, bathing, etc. The hardness increases due to mixing of domestic waste and increase in temperature (6). Hardness of water indicates water quality as it is not a pollution parameter (18) (Table 6).

Table 6: Classification of water based on hardness by Sawyer (1960)

\begin{tabular}{|c|c|}
\hline Hardness as $\mathrm{CaCO}_{3} \mathrm{ppm}$ & Water Class \\
\hline $0-75$ & Soft \\
\hline $75-100$ & Moderately hard \\
\hline $150-3000$ & Hard \\
\hline$>3000$ & Very hard \\
\hline
\end{tabular}

\section{Calcium hardness}

Calcium is essential for all organisms, being an important cell wall constituent and regulates various physiological functions in animals too. Calcium hardness was observed between $178 \mathrm{ppm}$ at site 3 during phase II and $560 \mathrm{ppm}$ at site I during phase I (Graph 7). The range of calcium content in ground water is largely dependent on the solubility of calcium carbonate, sulphide and rarely chloride (13).

\section{Magnesium hardness}

Magnesium solubility in water is around five times that of calcium (13). Magnesium ranged from $50 \mathrm{mg} / \mathrm{lit}$ at site 2 during phase III to $530 \mathrm{mg} /$ lit at site 1 during phase I (Graph 8 ). Calcium and magnesium together is the cause of water hardness.

\section{Chloride}

Chloride ion is a predominant natural form of chlorine and is extremely soluble in water. The major sources of chloride in natural water are sedimentary rocks (11). Chlorides ranged from $3.7 \mathrm{mg} /$ lit at site 3 during phase I while it was 7.44 $\mathrm{mg} /$ lit at site 2 during phase I (Graph 9). However, in natural fresh water, quite low concentration is found (9). The chloride content may be increased due to domestic water and fertilizers (7).

\section{Phosphate}

Phosphorus in water occurs mainly in orthophosphate, condensed phosphate and organically bound phosphate. The microbial detraction of organic matter releases the Phosphorus in phosphate form (11). The quality criteria of Phosphorus in waters is only to check the unwanted algal growth (5). The phosphate value ranged from $0.06 \mathrm{mg} / \mathrm{lit}$ at site 3 during phase II to $1.02 \mathrm{mg} /$ lit at site 1 during phase III

\section{Volume 4 Issue 11, November 2015}




\section{International Journal of Science and Research (IJSR) \\ ISSN (Online): 2319-7064 \\ Index Copernicus Value (2013): 6.14 | Impact Factor (2014): 5.611}

(Graph 10). Phosphorus in eutrophication process is regarded as the key element (4).

\section{Sodium}

Sodium has wide variations in its concentration in ground water (13). The sodium content of the samples ranged from $9.49 \mathrm{ppm}$ at site 3 during phase II to $28.23 \mathrm{ppm}$ at site 1 during phase I (Graph 11). Domestic sewage and effluent are the main source of sodium (17).

\section{Potassium}

The analysis of water samples in the study area indicates that a potassium value varies between 0.99 to $9.26 \mathrm{ppm}$. The minimum value $0.99 \mathrm{ppm}$ was found at site 3 during phase I whereas maximum value $9.26 \mathrm{ppm}$ was found at site 4 during phase I (Graph 12). Potassium concentration in ground water is very less as compared to sodium (nearly one - tenth or one - hundred that of sodium). The fact is that the potassium minerals are resistant to decomposition by weathering (13).

\section{Conclusion}

The study of physical and chemical characteristics of water provides a considerable insight into the quality of water present in sacred groves. Though the rate of change in water quality of sacred groves varies from site to site with maximum in area receiving anthropogenic disturbance, yet, the impacts has been actually observed throughout the sacred groves water quality in undesirable changes being accompanied by wide environmental degradation. From the present study, it is clear that the three sacred groves still maintain good water quality but water quality in Panchi K Baba sacred grove is getting change due to anthropogenic activities. Panchi K Baba sacred grove may reach to a critical stage from all ecological angles and if proper conservation measures are not taken, the sacred grove is likely to deteriorate further. Therefore, the water quality in Panchi K Baba sacred grove must be protected by the responsible priest and local people by restricting or precluding certain type of activities which is fruitful for the growth of sacred grove. Hence, the sacred groves support the provisional ecosystem services in the form of fresh water.

\section{Acknowledgement}

The authors are especially thankful to Ministry of Environment and Forests, New Delhi for providing financial support as a part of all India co-ordinated research project on sacred groves. The authors are thankful to School of Studies in Botany, Jiwaji University, Gwalior for providing necessary laboratory facilities and support.

\section{References}

[1] APHA, (1998) Standard Methods for the Examination of Water and Wastewater (Methods: 2340 C. EDTA Titrimetric Method)

[2] Barikh, K.S., Malhotra,C.K., Haridasan, K., Janarthanam, J., Parthasarathy, N. and Subhash Chandra, D. M. (2012) Assessment of ecosystem services of sacred groves in India - A methodology manual, Ministry of Environment and Forests, New Delhi.

[3] Carroll, D. (1962) Rainwater as a chemical agent of geologic processes a review, USGS Water Supply paper, pp 1535 .

[4] Fokmare, A.K. and Musaddiq, M. (2002) A study on physico-chemical characteristics of Kakshi lake and Purna river wastes in Akola district of Maharashtra (India). Natl. Environ. Poll. Technol., 1, 261-263.

[5] Goel, P.K. (2009) Water pollution causes, effects and control, Revised $2^{\text {nd }}$ edition, New Age International $(P)$ Ltd. Publisher, 223.

[6] Goyal, M., Dhar, D.N. and Rupainwar, D.C. (2006) An assessment of ground water pollution and its chemical quality in some parts of Unnao district. Indian Journal of Environ. Prot., 26(2), 148-152.

[7] Guru Prasad, B. (2005) Assessment of water quality in canals of Krishna delta area of Andhra Pradesh. Nat. Env and Poll. Tech., 4(4), 521-523.

[8] Hem, J.D. (1959) Study and interpretation of the chemical characteristics of natural water. US Geol Survey Water - Supply Paper, 1473, 261- 68.

[9] Manderia,S. and Manderia, H.K. (2014) Monitoring and analysis of qualitative characteristics of holy Kshipra river at Ujjain city (M.P.). The International Journal of Science and Technology, 2(11), 174-179.

[10] Manderia,S., Jahangeer,M.R. and Manderia,K. (2014) To evaluate the water quality status and responsible factors for variation in Anchar lake, Kashmir. Journal of Environmental Science, Toxicology and Food Technology, 8(2), 55-62.

[11] Nighojkar, A. and Dohare, D. (2014) Physicochemical parameters for testing of present water quality of Khan river at Indore, India. International Research Journal of Environmental Sciences, 3(4), 74-81.

[12] Patil, D.S. (2003) Ecological studies in some lentic water bodies of Kolhapur city, Ph.D. Thesis. Shivaji University, Kolhapur.

[13] Pradhan, B. and Pirasteh, S. (2011) Hydro-Chemical analysis of ground water of the basaltic catchments: Upper Bhatsai region, Maharashtra. The Open Hydrology Journal, 5, 51-57.

[14] Ravikumar, M.S., Manjappa, B. R., Kiran, E.T., Puttaiahand, A.N., Patel. (2006) Physicochemical characterization of Neelgunda tank near Haranhalli, Devangere. Indian Journal of Environ. Prot., 26 (2), 125-128.

[15] Sandereson, B.B. (1994) Manual of water and waste water analysis, NEERI, Nagpur.

[16] Sawyer, C.H. (1960) Chemistry for Sanitary Engineers, New York. McGraw-Hill Book Co., Inc.

[17] Sawyer,C.N., McCarty, P.L. and Parkin, G.F. (2000) Chemistry for Environmental Engineering $4^{\text {th }}$ Edition. Tata McGraw-Hill Publishing Company Limited.

[18] Sharma, R., Jikka, J., Bajpai, N. and Waghela (2012) Impact of domestic sewage and industrial effluent on water quality of the Khan river, Indore (India). Poll. Res., 31 (2): 289-296.

[19] Vyas, A., Mishra, D.D., Bajapai, A., Dixit, S. and Verma, V. (2006) Environmental impact of idol immersion activity on lakes of Bhopal. India. Asian $J$. exp. Sci., 20 (2), 289-296. 


\section{International Journal of Science and Research (IJSR) \\ ISSN (Online): 2319-7064}

Index Copernicus Value (2013): 6.14 | Impact Factor (2014): 5.611

Table 2: Physicochemical characteristics of water samples in monsoon season (Phase I)

\begin{tabular}{|c|c|c|c|c|c|c|}
\hline S.No. & Parameter & Units & Site 1 & Site 2 & Site 3 & Site 4 \\
\hline 1. & $\mathrm{pH}$ & - & 7.5 & 7.8 & 7.4 & 6.8 \\
\hline 2. & $\mathrm{EC}$ & $\mu \mathrm{S} / \mathrm{cm}$ & 612 & 155 & 229 & 218.5 \\
\hline 3. & $\mathrm{TDS}$ & $\mathrm{mg} / \mathrm{lit}$ & 391.6 & 99.2 & 146.5 & 139.8 \\
\hline 4. & Dissolved oxygen & $\mathrm{mg} / \mathrm{lit}$ & 6.24 & 6.55 & 8.9 & 6.9 \\
\hline 5. & Total alkalinity & $\mathrm{mg} / \mathrm{lit}$ & 310 & 110 & 85 & 70 \\
\hline 6. & Total hardness & $\mathrm{ppm}$ & 1090 & 395 & 465 & 450 \\
\hline 7. & Ca hardness & $\mathrm{ppm}$ & 560 & 310 & 350 & 265 \\
\hline 8. & Mg hardness & $\mathrm{ppm}$ & 530 & 85 & 115 & 135 \\
\hline 9. & Chloride & $\mathrm{mg} / \mathrm{lit}$ & 4.10 & 7.44 & 3.7 & 4.25 \\
\hline 10. & Phosphate & $\mathrm{mg} / \mathrm{lit}$ & 0.99 & 0.60 & 0.55 & 0.075 \\
\hline 11. & Sodium & $\mathrm{ppm}$ & 28.23 & 19.30 & 11.67 & 30.72 \\
\hline 12. & Potassium & $\mathrm{ppm}$ & 3.98 & 2.58 & 0.99 & 9.26 \\
\hline
\end{tabular}

Table 3: Physicochemical characteristics of water samples in winter season (Phase II)

\begin{tabular}{|c|c|c|c|c|c|c|}
\hline S.No. & Parameter & Units & Site 1 & Site 2 & Site 3 & Site 4 \\
\hline 1. & $\mathrm{pH}$ & - & 6.80 & 8.5 & 7.2 & 6.7 \\
\hline 2. & $\mathrm{EC}$ & $\mu \mathrm{S} / \mathrm{cm}$ & 666 & 165 & 242 & 298 \\
\hline 3. & TDS & $\mathrm{mg} / \mathrm{lit}$ & 426.2 & 105.6 & 154.6 & 190.4 \\
\hline 4. & Dissolved oxygen & $\mathrm{mg} / \mathrm{lit}$ & 5.65 & 6.05 & 6.46 & 6.05 \\
\hline 5. & Total alkalinity & $\mathrm{mg} / \mathrm{lit}$ & 300 & 80 & 120 & 160 \\
\hline 6. & Total hardness & $\mathrm{ppm}$ & 1040 & 310 & 415 & 395 \\
\hline 7. & Ca hardness & $\mathrm{ppm}$ & 520 & 190 & 178 & 224 \\
\hline 8. & Mg hardness & $\mathrm{ppm}$ & 520 & 120 & 219 & 171 \\
\hline 9. & Chloride & $\mathrm{mg} / \mathrm{lit}$ & 5.31 & 7.21 & 4.79 & 5.32 \\
\hline 10. & Phosphate & $\mathrm{mg} / \mathrm{lit}$ & 0.88 & 0.79 & 0.06 & 0.12 \\
\hline 11. & Sodium & $\mathrm{ppm}$ & 24.2 & 15.9 & 9.49 & 21.67 \\
\hline 12. & Potassium & $\mathrm{ppm}$ & 2.96 & 2.1 & 4.29 & 7.45 \\
\hline
\end{tabular}

Table 4: Physicochemical characteristics of water samples in summer season (Phase III)

\begin{tabular}{|c|c|c|c|c|c|c|}
\hline S.No. & Parameter & Units & Site 1 & Site 2 & Site 3 & Site 4 \\
\hline $\mathbf{1 .}$ & $\mathbf{p H}$ & - & 7.5 & 7.8 & 7.4 & 6.8 \\
\hline $\mathbf{2 .}$ & $\mathbf{E C}$ & $\mu \mathrm{S} / \mathrm{cm}$ & 625 & 158 & 218 & 235 \\
\hline $\mathbf{3 .}$ & TDS & $\mathrm{mg} / \mathrm{lit}$ & 400 & 101.2 & 139.5 & 150.4 \\
\hline $\mathbf{4 .}$ & Dissolved oxygen & $\mathrm{mg} / \mathrm{lit}$ & 6.2 & 6.7 & 8.13 & 7.1 \\
\hline $\mathbf{5 .}$ & Total alkalinity & $\mathrm{mg} / \mathrm{lit}$ & 280 & 110 & 167 & 76 \\
\hline $\mathbf{6 .}$ & Total hardness & $\mathrm{ppm}$ & 995 & 340 & 441 & 498 \\
\hline $\mathbf{7 .}$ & Ca hardness & $\mathrm{ppm}$ & 550 & 290 & 338 & 265 \\
\hline $\mathbf{8 .}$ & Mg hardness & $\mathrm{ppm}$ & 445 & 50 & 103.5 & 233 \\
\hline $\mathbf{9 .}$ & Chloride & $\mathrm{mg} / \mathrm{lit}$ & 4.15 & 7.05 & 3.9 & 4.45 \\
\hline $\mathbf{1 0 .}$ & Phosphate & $\mathrm{mg} / \mathrm{lit}$ & 1.02 & 0.80 & 0.6 & 0.14 \\
\hline $\mathbf{1 1 .}$ & Sodium & $\mathrm{ppm}$ & 27.25 & 20.01 & 11.43 & 27.13 \\
\hline $\mathbf{1 2 .}$ & Potassium & $\mathrm{ppm}$ & 4.02 & 2.95 & 1.15 & 8.28 \\
\hline
\end{tabular}

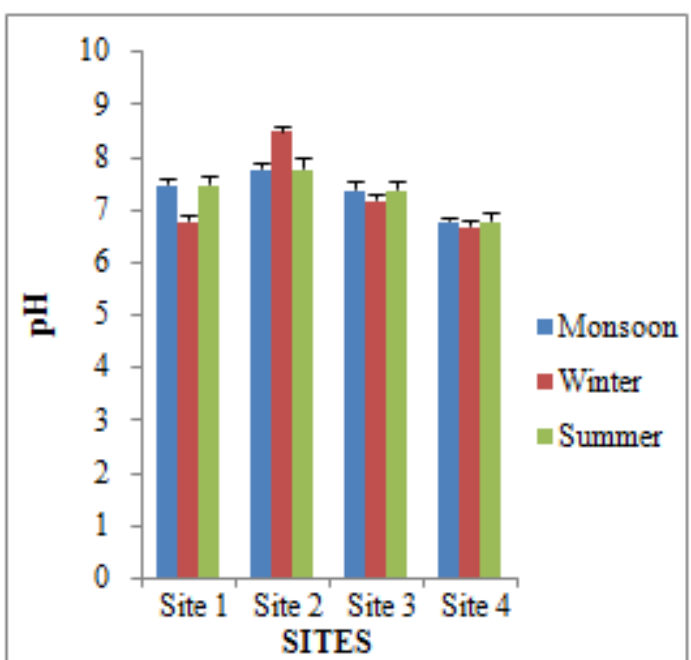

Graph 1: $\mathrm{pH}$ variation

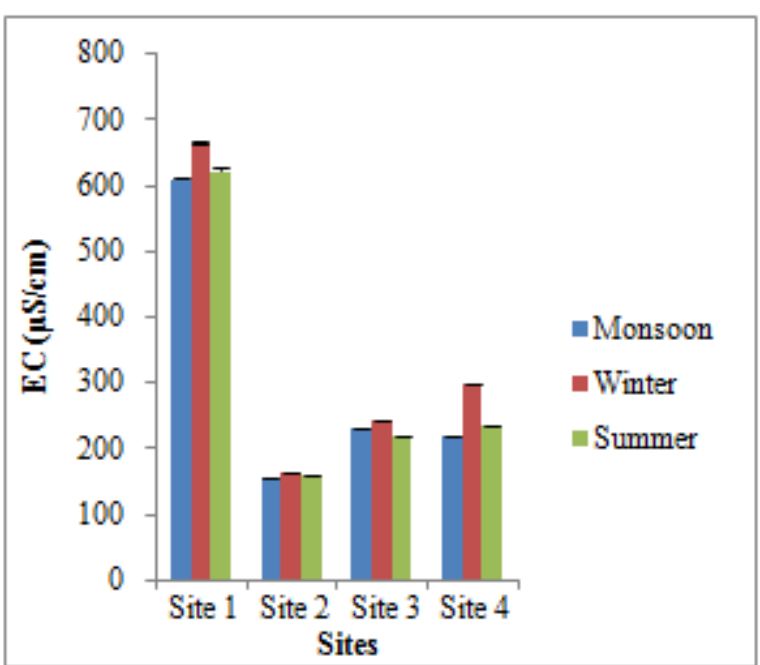

Graph 2: Electrical Conductivity $(\mu \mathrm{S} / \mathrm{cm})$

Volume 4 Issue 11, November 2015 www.ijsr.net 
International Journal of Science and Research (IJSR)

ISSN (Online): 2319-7064

Index Copernicus Value (2013): 6.14 | Impact Factor (2014): 5.611
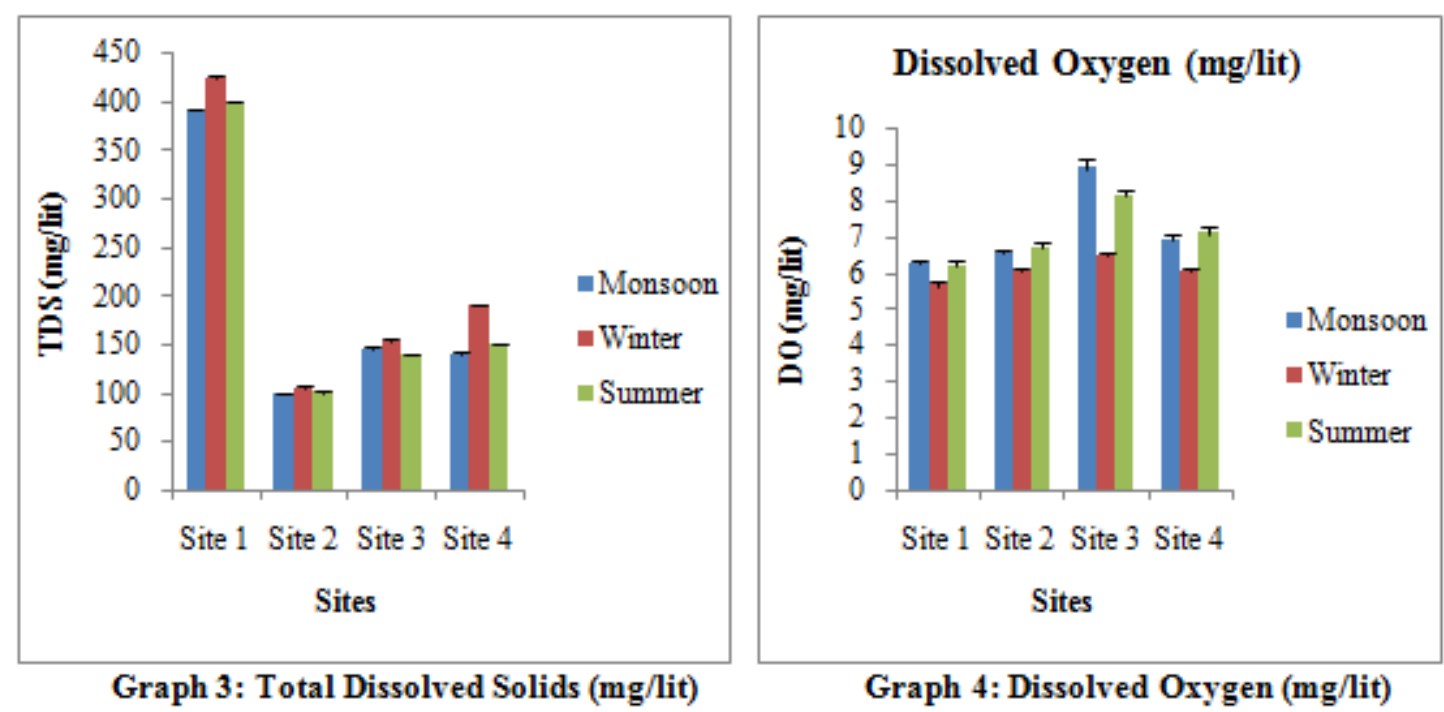

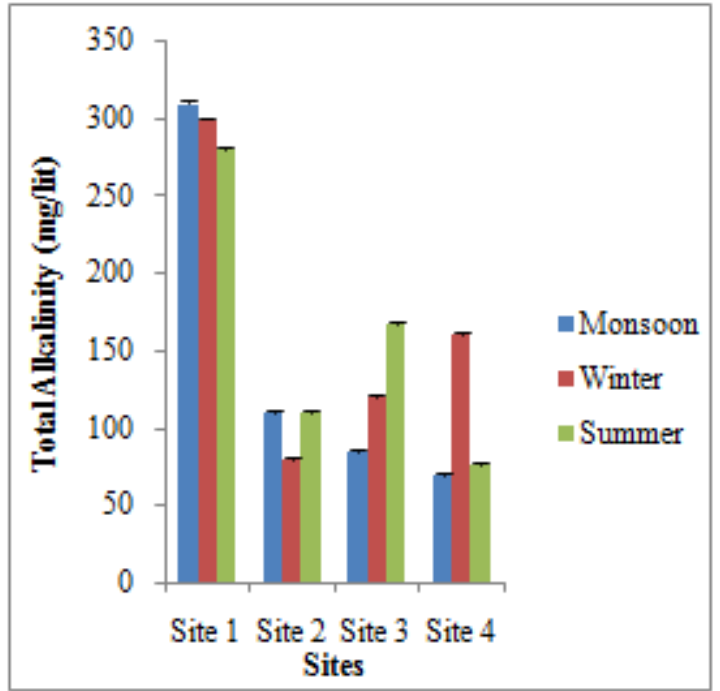

Graph 5: Total Alkalinity (mg/lit)

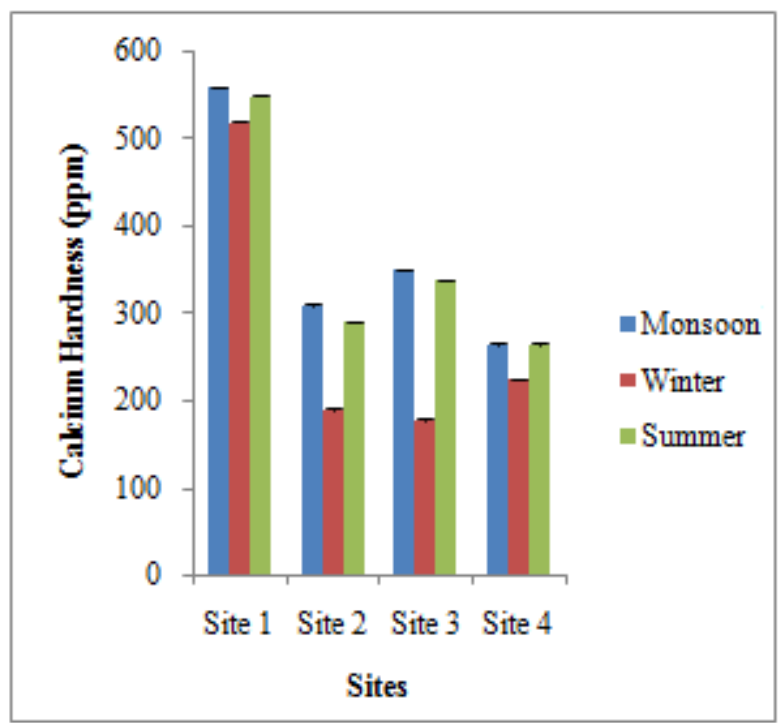

Graph 7: Calcium Hardness (ppm)

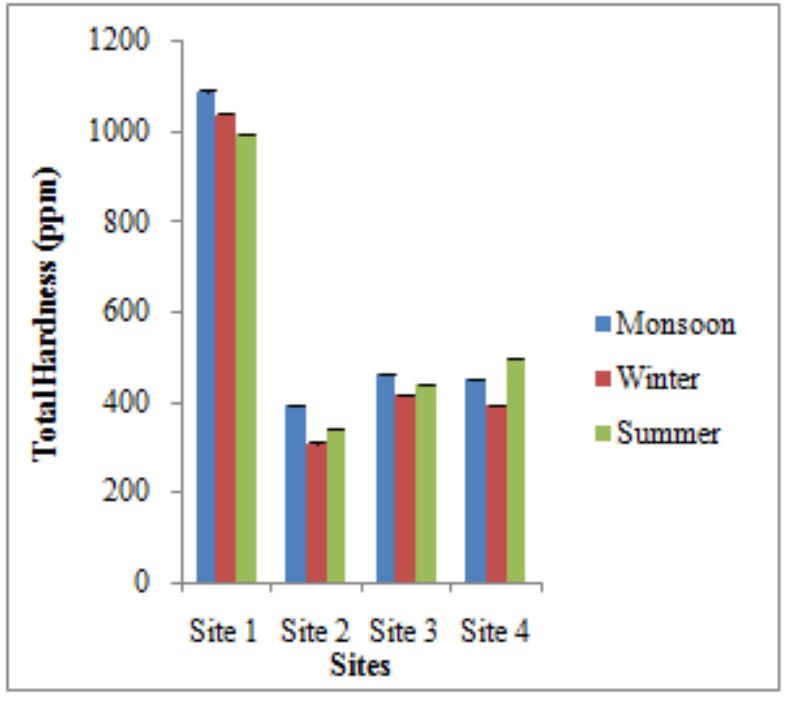

Graph 6: Total Hardness (ppm)

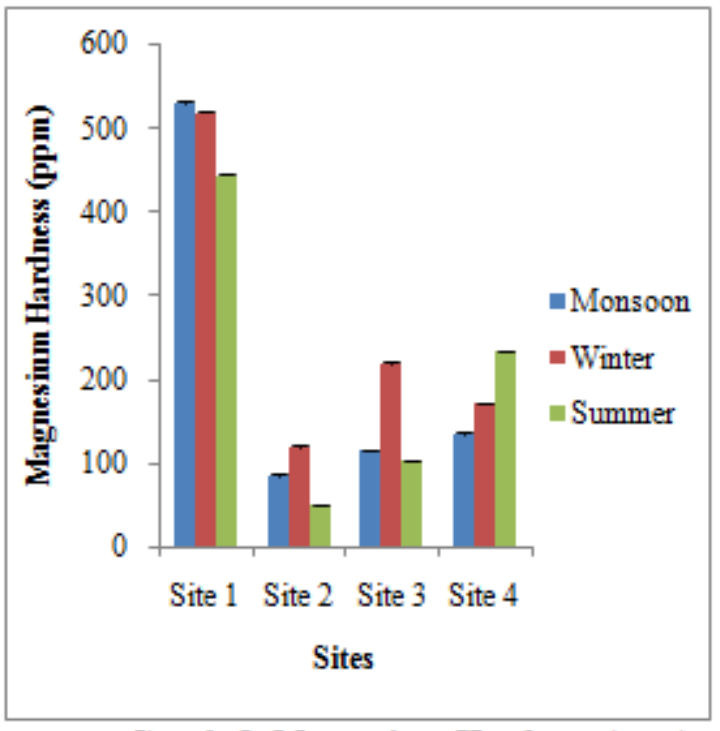

Graph 8: Magnesium Hardness (ppm) 
International Journal of Science and Research (IJSR)

ISSN (Online): 2319-7064

Index Copernicus Value (2013): 6.14 | Impact Factor (2014): 5.611

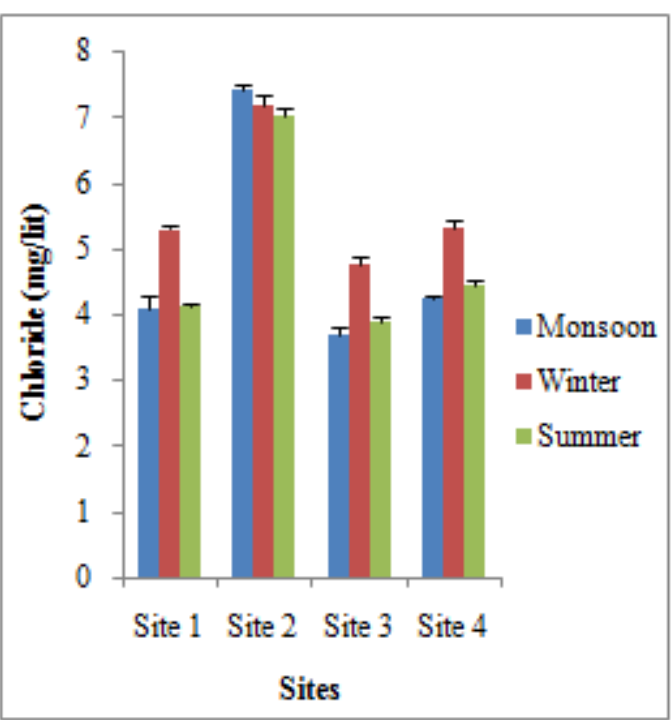

Graph 9: Chloride (mg/lit)

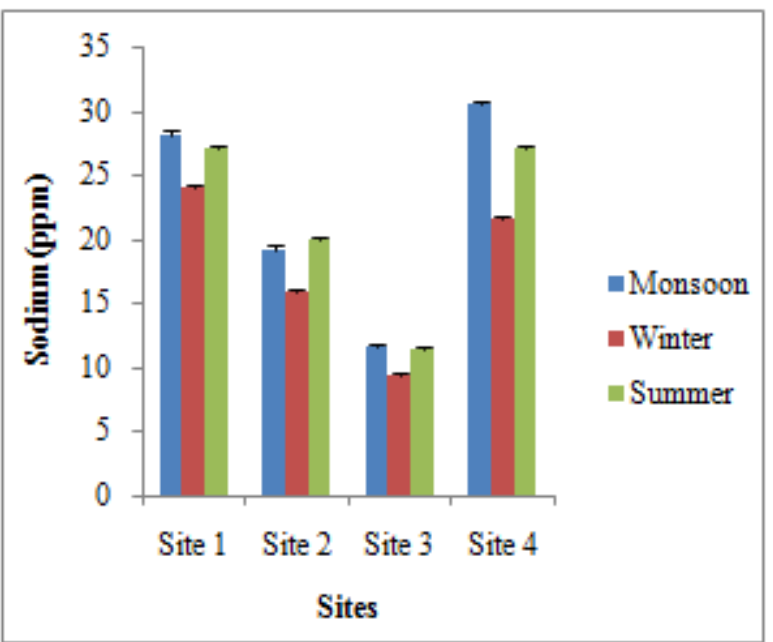

Graph 11: Sodium (ppm)

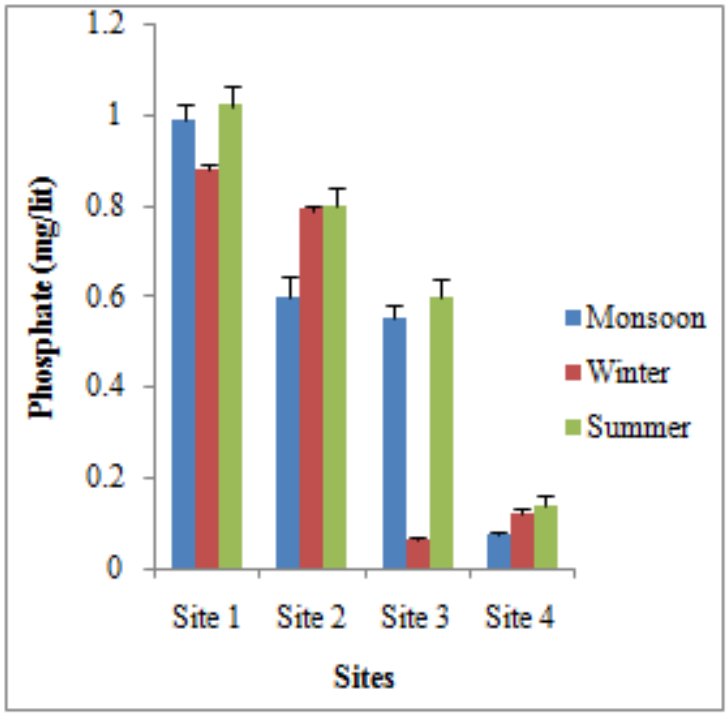

Graph 10: Phosphate (mg/lit)

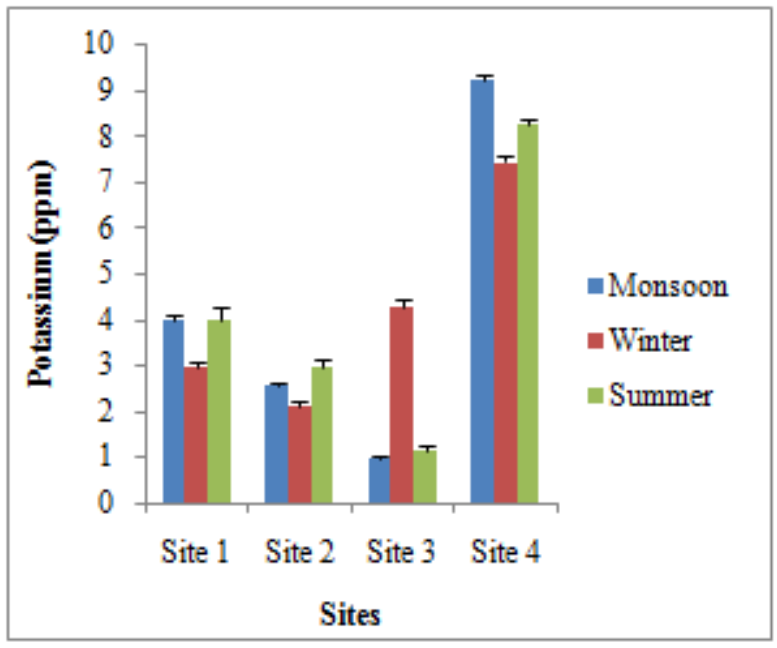

Graphl2. Potassium (ppm)

Volume 4 Issue 11, November 2015 